(c) American Dairy Science Association, 2007.

\title{
Dietary Energy Source in Dairy Cows in Early Lactation: Energy Partitioning and Milk Composition
}

\author{
A. T. M. van Knegsel, ${ }^{*} \dagger^{1}$ H. van den Brand, ${ }^{*}$ J. Dijkstra, $\dagger$ W. M. van Straalen, $\neq$ \\ M. J. W. Heetkamp, ${ }^{*}$ S. Tamminga,† and B. Kemp* \\ *Adaptation Physiology Group, and \\ †Animal Nutrition Group, Wageningen Institute of Animal Sciences, Wageningen University, PO Box 338, \\ $6700 \mathrm{AH}$ Wageningen, the Netherlands \\ ¥Schothorst Feed Research, PO Box 533, 8200 AM Lelystad, the Netherlands
}

\begin{abstract}
Metabolic problems related to negative energy balance suggest a role for the balance in supply of lipogenic and glucogenic nutrients. To test the effect of lipogenic and glucogenic nutrients on energy partitioning, energy balance and nitrogen balance of 16 lactating dairy cows were determined by indirect calorimetry in climate respiration chambers from wk 2 to 9 postpartum. Cows were fed a diet high in lipogenic nutrients or a diet high in glucogenic nutrients from wk 3 prepartum until wk 9 postpartum. Diets were isocaloric (net energy basis) and equal in intestinal digestible protein. There was no effect of diet on metabolizable energy intake and heat production. Cows fed the lipogenic diet partitioned more energy to milk than cows fed the glucogenic diet $\left[1,175 \pm 18\right.$ vs. $\left.1,073 \pm 12 \mathrm{~kJ} /\left(\mathrm{kg}^{0.75} \cdot \mathrm{d}\right)\right]$ and had a higher milk fat yield $(1.89 \pm 0.02$ vs. $1.67 \pm 0.03 \mathrm{~kg} / \mathrm{d})$. The increase in milk fat production was caused by an increase in C16:0, C18:0, and C18:1 in milk fat. No difference was found in energy retained as body protein, but energy mobilized from body fat tended to be higher in cows fed the lipogenic diet than in cows fed the glucogenic diet $\left[190 \pm 23\right.$ vs. $\left.113 \pm 26 \mathrm{~kJ} /\left(\mathrm{kg}^{0.75} \cdot \mathrm{d}\right)\right]$. Overall, results demonstrate that energy partitioning between milk and body tissue can be altered by feeding isocaloric diets differing in lipogenic and glucogenic nutrient content.
\end{abstract}

Key words: energy balance, milk fat composition, lipogenic nutrient, glucogenic nutrient

\section{INTRODUCTION}

Late gestation and early lactation can be considered as the most critical period for high-producing dairy cows. This period is often characterized by metabolic disorders such as fatty liver, ketosis (Grummer, 1993),

Received July 28, 2006.

Accepted October 30, 2006.

${ }^{1}$ Corresponding author: Ariette.vanKnegsel@wur.nl and ruminal acidosis (Owens et al., 1998), and reduced fertility (Butler, 2003). Metabolic and reproductive disorders in dairy cows in early lactation have been allocated to a negative energy status, resulting from a genetic potential for high milk production accompanied by a delay in feed intake peripartum (Veerkamp et al., 2003).

Several reviews have indicated dietary energy sources to be an important factor in the prevention and severity of negative energy balance (NEB) and related metabolic disorders (e.g., Grummer and Carroll, 1988; Gong, 2002). The characteristics of NEB-related metabolic problems suggest a role for the balance in availability of lipogenic and glucogenic nutrients (Adler, 1970; van Knegsel et al., 2005). In ruminants, lipogenic nutrients originate either from fiber that stimulates the ruminal production of acetate and butyrate or from dietary fat, or are derived from body reserves. Glucogenic nutrients originate from starch escaped from rumen degradation or gluconeogenesis. In descending order of importance, propionic acid, glucogenic AA and lactic acid are the main contributors to gluconeogenesis in ruminants (Brockman, 2005). The contribution of intestinally digested starch toward glucose is highly variable, depending on factors including dietary source of rumen-resistant starch, technological treatment, and intake level (Mills et al., 1999).

Over 40 yr ago, it was suggested that milk-fat-depressing diets lower the priority for milk fat production relative to fat deposition in body reserves (Van Soest, 1963). This implies that lipogenic nutrients, which increase milk fat yield (Jerred et al., 1990), increase the partitioning of ME into milk (Baldwin et al., 1985) and consequently decrease the partitioning of ME into body reserves. However, the effect of lipogenic nutrients on milk fat also depends on the degree and type of saturation of dietary fat. Polyunsaturated fatty acids and specific intermediates of their biohydrogenation in the rumen, notably C18:2 trans-10, cis-12, depress milk fat (Bauman et al., 2006) in contrast to saturated fat sources (Baumgard et al., 2001; Schroeder et al., 2003). 
Table 1. Ingredient and chemical composition of glucogenic and lipogenic concentrates

\begin{tabular}{|c|c|c|}
\hline \multirow[b]{2}{*}{ Item } & \multicolumn{2}{|c|}{ Concentrate } \\
\hline & Glucogenic & Lipogenic \\
\hline \multicolumn{3}{|l|}{ Ingredient (g/kg) } \\
\hline Rapeseed meal & 127.2 & 98.5 \\
\hline Lupins & - & 166.2 \\
\hline Corn & 265.6 & - \\
\hline Corn gluten feed & - & 63.3 \\
\hline Milocorn & 250.0 & - \\
\hline Palm kernel, expeller & 31.6 & 125.0 \\
\hline Sugarbeet pulp & - & 294.5 \\
\hline Peas & 131.5 & - \\
\hline Soybean meal, formaldehyde treated & 124.0 & - \\
\hline Rapeseed meal, formaldehyde treated & - & 148.3 \\
\hline Megalac $^{1}$ & - & 25.0 \\
\hline Molasses-cane & 40.0 & 40.0 \\
\hline Palm oil & - & 25.0 \\
\hline Calcium carbonate & 13.6 & - \\
\hline Magnesium oxide & 0.7 & - \\
\hline Sodium chloride & 8.3 & 6.6 \\
\hline Mineral-vitamin mixture ${ }^{2}$ & 7.5 & 7.5 \\
\hline \multicolumn{3}{|l|}{ Chemical composition } \\
\hline $\mathrm{DM}(\mathrm{g} / \mathrm{kg})$ & 873.2 & 895.8 \\
\hline $\mathrm{CP}(\mathrm{g} / \mathrm{kg}$ of $\mathrm{DM})$ & 201.8 & 212.7 \\
\hline Crude fat & 31.0 & 85.9 \\
\hline NDF & 152.2 & 350.6 \\
\hline Starch & 448.0 & 3.8 \\
\hline Ash & 60.9 & 98.5 \\
\hline $\mathrm{DVE}^{3}$ & 137 & 134 \\
\hline $\mathrm{OEB}^{4}$ & 13 & 22 \\
\hline $\mathrm{NE}_{\mathrm{L}}^{5}(\mathrm{MJ} / \mathrm{kg})$ & 6.69 & 6.69 \\
\hline
\end{tabular}

${ }^{1}$ Ca salts of palm fatty acids (Volac, Hertfordshire, UK).

${ }^{2}$ Contained per kilogram of mix: $115 \mathrm{~g}$ of $\mathrm{Ca}\left(\mathrm{CaCO}_{3}\right)$; $385 \mathrm{mg}$ of $\mathrm{Mg}(\mathrm{MgO}) ; 1.67 \mathrm{mg}$ of $\mathrm{Cu}\left(\mathrm{CuSO}_{4} \cdot 5 \mathrm{H}_{2} \mathrm{O}\right) ; 1.34 \mathrm{mg}$ of $\mathrm{Mn}\left(\mathrm{MnO}_{2}\right) ; 2.67$ $\mathrm{mg}$ of $\mathrm{Zn}\left(\mathrm{ZnSO}_{4} \cdot 7 \mathrm{H}_{2} \mathrm{O}\right) ; 0.04 \mathrm{mg}$ of $\mathrm{Co}\left(\mathrm{CoSO}_{4} \cdot 7 \mathrm{H}_{2} \mathrm{O}\right) ; 0.13 \mathrm{mg}$ of I (KI); $0.03 \mathrm{mg}$ of $\mathrm{Se}\left(\mathrm{Na}_{2} \mathrm{SeO}_{3}\right) ; 667,000 \mathrm{IU}$ of vitamin A; 160,000 IU of cholecalciferol (Premix 2031, PreMervo, Utrecht, the Netherlands).

${ }^{3}$ Intestinal digestible protein (Tamminga et al., 1994).

${ }^{4}$ Degraded protein balance (Tamminga et al., 1994).

${ }^{5}$ Net energy for lactation calculated with VEM system (Van Es, 1975).

On the other hand, glucogenic nutrients decrease milk fat content (e.g., Grum et al., 1996; Ruppert et al., 2003) and increase plasma insulin (Miyoshi et al., 2001). These observations suggest that glucogenic nutrients stimulate body fat deposition and the partitioning of ME into body tissue. This indicates possibilities to improve the energy balance of dairy cows in early lactation by increasing the availability of glucogenic nutrients at the expense of lipogenic nutrients.

In addition, not only milk fat yield, but also milk fatty acid composition is affected by lactation stage (Palmquist et al., 1993; Garnsworthy et al., 2006) and diet composition (Chilliard and Ferlay, 2004). Both dietary fat addition and body fat mobilization increase the bioavailability of C18 fatty acids (Ward et al., 2002). Furthermore, the early lactation period is usually characterized by a higher concentrate intake compared with
Table 2. Ingredient and chemical composition of glucogenic and lipogenic diets ${ }^{1}$

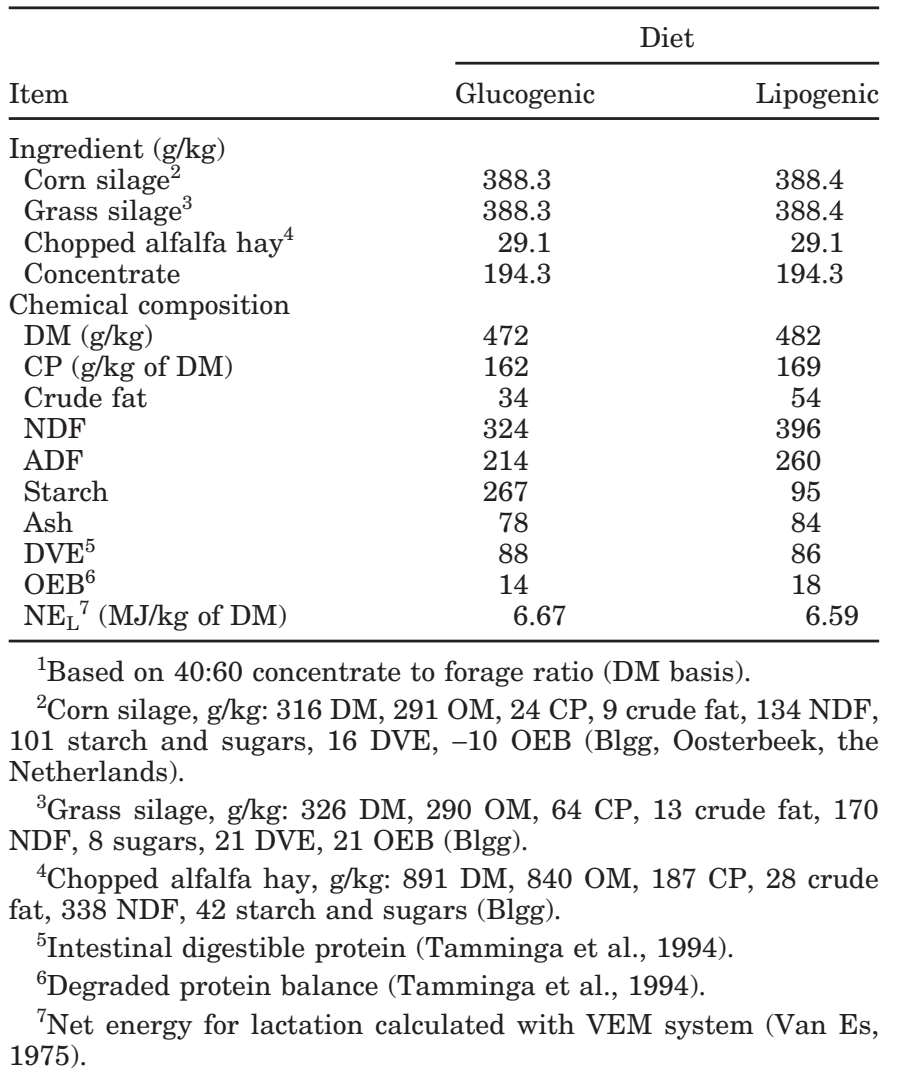

the mid and late lactation or dry period, which results in a lower ruminal acetate:propionate ratio (Bannink et al., 2006). Accordingly, the availability of precursors for de novo lipogenesis is reduced (Bauman and Griinari, 2003), resulting in a decrease in medium- and short-chain fatty acids in milk fat. Thus, dietary fat, body fat, and the reduced acetate:propionate ratio may increase the proportion of long-chain fatty acids in milk fat. Hence, a relationship between dietary energy source and an NEB with milk fat composition can be expected. However, very few comparisons on the effect of the interaction between body fat mobilization and diet composition on milk fat composition have been made (Smith et al., 1978).

The objective of this study was to compare on an isocaloric basis the effects of a mainly glucogenic or a mainly lipogenic diet on energy partitioning and milk fat composition in early-lactation dairy cows in a NEB. The companion paper (van Knegsel et al., 2007) focuses on the effects of dietary energy source on blood metabolites and metabolic hormones and their relationship with the determined energy balance by indirect calorimetry. 
Table 3. Fatty acid composition of the glucogenic and lipogenic concentrate $^{1}$

\begin{tabular}{lcc}
\hline & \multicolumn{2}{c}{ Concentrate } \\
\cline { 2 - 3 } $\begin{array}{l}\text { Fatty acid } \\
\text { g/kg of DM) }\end{array}$ & Glucogenic & Lipogenic \\
\hline$\leq 10: 0$ & 0.14 & 0.55 \\
$12: 0$ & 0.97 & 3.86 \\
$14: 0$ & 0.37 & 1.37 \\
$16: 0$ & 3.18 & 12.16 \\
$16: 1$ & 0.10 & 0.06 \\
$18: 0$ & 0.50 & 1.71 \\
$18: 1$ & 8.07 & 29.24 \\
$18: 2$ & 11.31 & 11.86 \\
$18: 3$ & 0.89 & 0.97 \\
$\geq 20: 0$ & 0.34 & 1.67 \\
Total & 25.89 & 63.44 \\
\hline
\end{tabular}

${ }^{1}$ Calculated according to Centraal Veevoederbureau (CentraalVeevoederbureau, 2005).

\section{MATERIALS AND METHODS}

\section{Experimental Design}

The Institutional Animal Care and Use Committee of Wageningen University approved the experimental protocol. Energy balance of 16 lactating dairy cows was determined as energy retention in body mass (ER) using climate respiration chambers (Verstegen et al., 1987) over 8 successive balance periods ( $1 \mathrm{wk}$ ) from wk 2 to 9 postpartum (pp). The animals were divided into 4 groups. Within each group, 1 pair of animals was assigned to each of 2 experimental diets 3 wk prepartum. Experimental diets were either mainly lipogenic or mainly glucogenic.

\section{Animals and Housing}

Sixteen Holstein-Friesian dairy cows, 4 cows per group, with comparable milk production $(>9,500 \mathrm{~kg}$ of fat- and protein-corrected milk per $305 \mathrm{~d}$ ), were selected from a group of 44 cows that were inseminated at synchronized ovulation (the Crestar+ method, Intervet, Boxmeer, the Netherlands). Ovulation was synchronized to obtain natural calving cows with at most $4 \mathrm{~d}$ variation in calving date. Selection of the 16 experimental cows was based on calving date. Postcalving, parity of the selected cows ranged from 2 to 4 . Within $1 \mathrm{wk}$ pp, 4 cows were transported and housed ( 2 cows per chamber) in 2 identical, large, open-circuit, indirect climate respiration chambers (Verstegen et al., 1987). Per group dietary treatment was assigned alternately to 1 of the 2 chambers. The cows were housed in the chamber in a tie stall. Chamber temperature was maintained at $16^{\circ} \mathrm{C}$ and relative humidity was set at $70 \%$. Air velocity was $<0.2 \mathrm{~m} / \mathrm{s}$. Cows were exposed to $16 \mathrm{~h}$ of light (0600 to $2200 \mathrm{~h}$ ) and $8 \mathrm{~h}$ of darkness. Body condition was scored ( 1 to 5 scale) every 3 wk from wk 3 prepartum until wk 9 pp. Body weight was recorded at the start and end of each 1-wk balance period. Cows were milked twice daily ( 0600 and $1700 \mathrm{~h}$ ) in the climate respiration chamber with a mobile milking system.

\section{Diets}

Cows were fed $1 \mathrm{~kg} / \mathrm{d}$ of the experimental concentrates 3 wk prepartum followed by $2 \mathrm{~kg} / \mathrm{d}$ in the last week prepartum. Roughage did not differ between diets and was supplied ad libitum; it consisted of grass silage, corn silage, and wheat straw in a 45:45:10 ratio (DM basis). Postpartum, wheat straw was replaced by 1.5 $\mathrm{kg} / \mathrm{d}$ of chopped alfalfa hay. Concentrate supply was increased stepwise by $0.5 \mathrm{~kg} / \mathrm{d}$ until concentrate intake reached $10.0 \mathrm{~kg} / \mathrm{d}$ with a concentrate to forage ratio of 40:60 (DM basis). Ingredient and chemical compositions of both concentrates and diets are presented in Table 1 and 2. Calculated fatty acid composition of the concentrates is presented in Table 3. Diets were fed as

Table 4. Dry matter intake, milk production, and milk composition of dairy cows fed a mainly glucogenic or mainly lipogenic diet during wk 2 to 9 of lactation

\begin{tabular}{|c|c|c|c|c|c|c|}
\hline \multirow[b]{2}{*}{ Variable } & \multicolumn{2}{|c|}{ Diet } & \multirow[b]{2}{*}{ SEM } & \multicolumn{3}{|c|}{$P$-value ${ }^{1}$} \\
\hline & Glucogenic & Lipogenic & & Diet (D) & Week (W) & $\mathrm{D} \times \mathrm{W}$ \\
\hline DMI (kg/d) & 20.8 & 20.7 & 0.5 & 0.94 & $<0.01$ & NS \\
\hline Milk yield (kg/d) & 39.8 & 39.8 & 0.7 & 0.88 & $<0.01$ & NS \\
\hline \multicolumn{7}{|l|}{ Milk lactose } \\
\hline$\%$ & 4.44 & 4.56 & 0.05 & 0.08 & 0.16 & NS \\
\hline $\mathrm{kg} / \mathrm{d}$ & 1.76 & 1.82 & 0.04 & 0.32 & $<0.01$ & NS \\
\hline \multicolumn{7}{|l|}{ Milk fat } \\
\hline$\%$ & 4.27 & 4.81 & 0.15 & 0.02 & $<0.01$ & NS \\
\hline $\mathrm{kg} / \mathrm{d}$ & 1.68 & 1.90 & 0.06 & 0.03 & 0.02 & 0.05 \\
\hline \multicolumn{7}{|l|}{ Milk protein } \\
\hline$\%$ & 3.11 & 3.13 & 0.06 & 0.64 & $<0.01$ & NS \\
\hline $\mathrm{kg} / \mathrm{d}$ & 1.23 & 1.24 & 0.03 & 0.66 & 0.11 & 0.02 \\
\hline
\end{tabular}

${ }^{1}$ Diet $\times$ week interaction was excluded from the model if not significant $(P>0.05)$. 


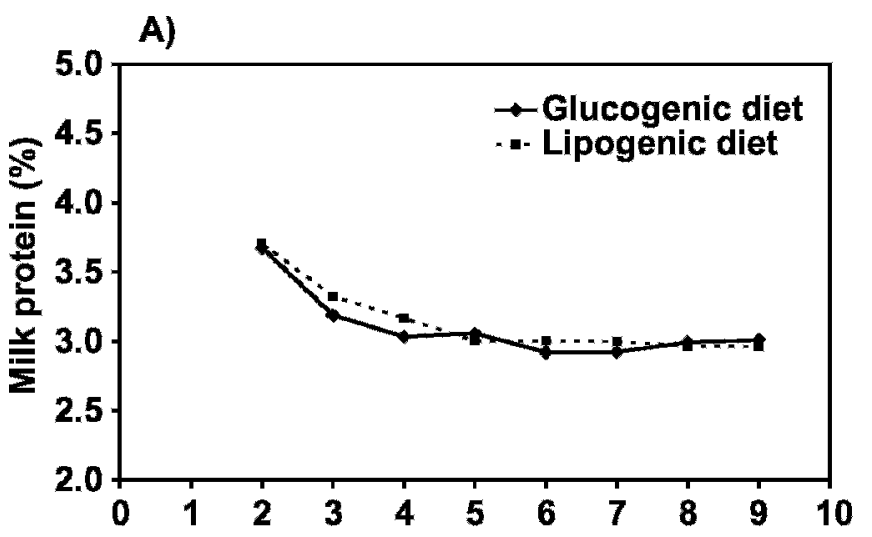

B)

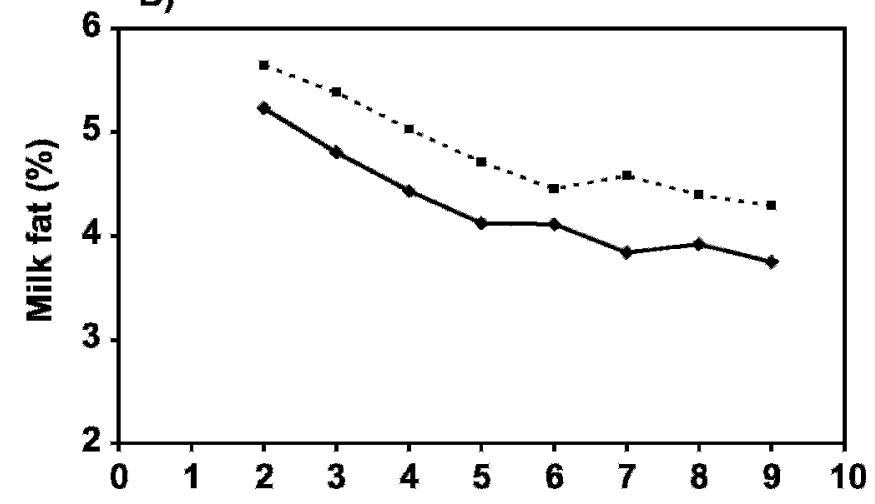

C)

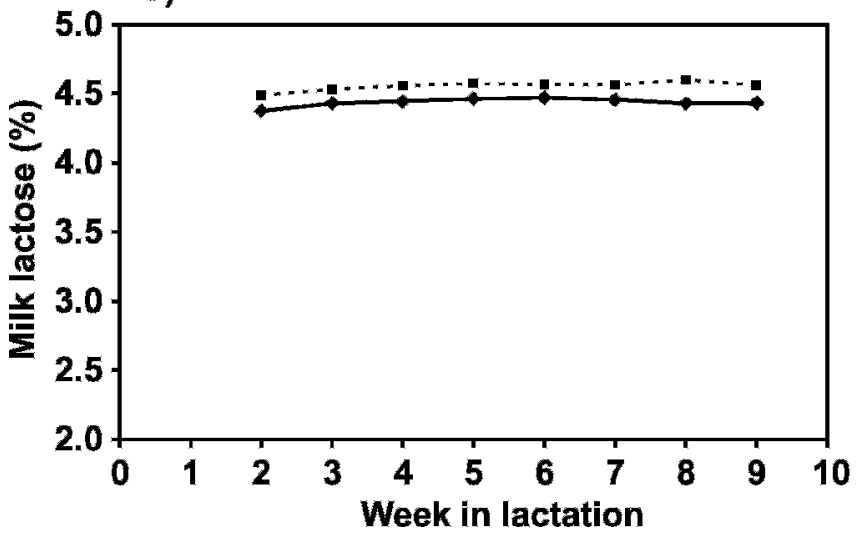

Figure 1. A) Milk protein content; B) milk fat content; and C) milk lactose content of dairy cows fed a mainly glucogenic or mainly lipogenic diet from wk 2 to 9 of lactation. Values represent means during 8 balance periods of 1 wk. Overall SEM: milk protein, 0.03; milk fat, 0.07 ; milk lactose, 0.01 .

TMR, were isocaloric according to the Dutch $\mathrm{NE}_{\mathrm{L}}$ system (Van Es, 1975), and were equal in intestinal digestible protein and degraded protein balance (DVE/OEB system; Tamminga et al., 1994). Diets were fed twice a day in equal proportions before milking.

\section{Energy and Nitrogen Balance}

Feces with urine were collected quantitatively per chamber, pooled per balance period, sampled for energy and nitrogen analysis, and stored at $-20^{\circ} \mathrm{C}$ until analysis. Feed intake was monitored per cow per balance period and feed samples were collected per day and pooled per balance period, sampled for energy and nitrogen analysis, and stored at $4^{\circ} \mathrm{C}$ until analysis. Milk was sampled each milking ( $3 \mathrm{~g} / \mathrm{kg}$ of milk), pooled per cow per balance period, and stored at $4^{\circ} \mathrm{C}$ during the balance period and at $-20^{\circ} \mathrm{C}$ after each balance period. Gross energy (GE) values of feed, energy in feces with urine, and energy in milk were measured using bomb calorimetry (IKA-C700, Janke \& Kunkel, Heitersheim, Germany) and $\mathrm{N}$ content by Kjeldahl analysis. Intake of ME per chamber was calculated from the GE content of the feed, feces with urine, and produced methane. Heat production (HP) was determined indirectly at 9min intervals by measuring the exchange of oxygen, carbon dioxide, and methane as described earlier (Verstegen et al., 1987). Energy retention in body mass was calculated by subtracting the HP and energy in milk from the ME. The total N retention (NR; g/d) was estimated from $\mathrm{N}$ in feed, feces, urine, milk, dust, and water that condensed on the heat exchanger, and in acidified liquid samples through which outflowing air from the chambers was led to trap aerial ammonia. Energy retention as body protein $\left(\mathbf{E R}_{\mathbf{p}}\right)$ was derived from the protein gain $(\mathrm{N} \times 6.25$; except $\mathrm{N}$ in milk $\times 6.38)$ multiplied by $23.6 \mathrm{~kJ} / \mathrm{g}$ (energetic value of body protein; ARC, 1980). Energy retention as fat $\left(\mathbf{E R}_{\mathbf{f}}\right)$ was calculated from the difference between ER and $\mathrm{ER}_{\mathrm{p}}$. Energy retention data are expressed per $\mathrm{kg}^{0.75}$, where the mean BW per cow per balance period was used to calculate the metabolic BW.

\section{Milk Yield and Composition}

Milk yield was recorded daily. Milk samples for fat, protein, and lactose analysis (ISO 9622, Melkcontrolestation, Zutphen, the Netherlands) were collected 4 times per balance period ( 2 morning and 2 evening milkings). An individual morning sample per balance period was stored at $-20^{\circ} \mathrm{C}$ until analysis for milk fatty acid composition.

For milk fatty acid analysis, the stored individual milk samples were heated to $50^{\circ} \mathrm{C}$ and directly centrifuged $(20 \mathrm{~min}$ at $1,600 \times \mathrm{g})$ at $4^{\circ} \mathrm{C}$. The upper layer (fat and cream) was collected and filtered on folded filter paper. The fat-and-cream mixture was collected from the filter and stored overnight at $-20^{\circ} \mathrm{C}$. The mixture was heated for $10 \mathrm{~min}$ at $50^{\circ} \mathrm{C}$. The oily substance was centrifuged at room temperature $(5 \mathrm{~min}$ at $1,130 \times \mathrm{g})$, and the fat fraction was transferred to a tube containing 
Table 5. Gross energy intake, $\mathrm{ME}$ intake, methane production, heat production, and energy retention in body mass of dairy cows fed a mainly glucogenic or lipogenic diet during wk 2 to 9 of lactation ${ }^{1}$

\begin{tabular}{|c|c|c|c|c|c|}
\hline \multirow[b]{2}{*}{ Variable } & \multicolumn{2}{|c|}{ Diet } & \multirow[b]{2}{*}{ SEM } & \multicolumn{2}{|c|}{$P$-value ${ }^{2}$} \\
\hline & Glucogenic & Lipogenic & & Diet & Week \\
\hline & \multicolumn{2}{|c|}{$\longrightarrow \mathrm{kJ} /\left(\mathrm{kg}^{0.75} \cdot \mathrm{d}\right) \longrightarrow$} & & & \\
\hline Gross energy intake (GE) & 3,415 & 3,492 & 122 & 0.67 & $<0.01$ \\
\hline Metabolizable energy intake (ME) & 2,079 & 2,124 & 74 & 0.68 & $<0.01$ \\
\hline ME:GE ratio (\%) & 60.7 & 60.8 & 0.6 & 0.90 & $<0.01$ \\
\hline Methane production & 179 & 178 & 9 & 0.96 & $<0.01$ \\
\hline Heat production & 1,096 & 1,124 & 30 & 0.54 & $<0.01$ \\
\hline Energy in milk & 1,075 & 1,173 & 23 & 0.01 & $<0.01$ \\
\hline Energy retention in body mass $(\mathrm{ER})^{3}$ & -94 & -172 & 28 & 0.12 & $<0.01$ \\
\hline Energy retention as body protein $\left(\mathrm{ER}_{\mathrm{p}}\right)$ & 19 & 18 & 7 & 0.89 & $<0.01$ \\
\hline Energy retention as body fat $\left(\mathrm{ER}_{\mathrm{f}}\right)$ & -113 & -190 & 24 & 0.09 & $<0.01$ \\
\hline
\end{tabular}

a small amount of anhydrous sodium sulfate. The milk fats were stored at $-20^{\circ} \mathrm{C}$ until analysis. Before analysis, samples were heated to $50^{\circ} \mathrm{C}$. A portion of $50 \mu \mathrm{L}$ was taken, weighed, and added to $5 \mathrm{~mL}$ of hexane, containing $0.02 \%$ C23 (Alltech, Breda, the Netherlands) as an internal standard. The glycerol-bound fatty acids were transesterified to methyl esters by vortexing 1 min with $200 \mu \mathrm{L}$ of sodium methanolate in methanol (30\%). The solution was neutralized with $1 \mathrm{~g}$ of sodium hydrogen sulfate and dried with anhydrous sodium sulfate. Fatty acid methyl esters (FAME) were injected into a gas chromatograph (Carlo Erba HRGC Mega 2, Fisons, Milan, Italy), equipped with a flame-ionization detector (detector temperature of $260^{\circ} \mathrm{C}$ ). The carrier gas was helium, and the inlet pressure $330 \mathrm{kPa}$. Samples were injected by split injection (split ratio 1:20), injection temperature was $260^{\circ} \mathrm{C}$. Separation of FAME was performed with a Supelco column $(100 \mathrm{~m} \times 0.25$ $\mathrm{mm} \times 0.2 \mu \mathrm{m}$; SP 2560, Sigma-Aldrich, Zwijndrecht, the Netherlands). The oven temperature was programmed from $140^{\circ} \mathrm{C}$ for $4 \mathrm{~min}$, followed by an increase of $4^{\circ} \mathrm{C} /$ min to $240^{\circ} \mathrm{C}$, and held for $30 \mathrm{~min}$. The FAME concentrations were determined by using the Chrom Card program (Thermo Finnigan, Milan, Italy) using the Supelco FAME mix (Sigma-Aldrich) as a standard.

\section{Statistical Analysis}

In groups 2 and 3, 3 cows in total were excluded from the experiment because of left displaced abomasum ( 1 cow fed a lipogenic diet, 2 cows fed a glucogenic diet). Therefore, values are based on 13 cows (glucogenic diet: $\mathrm{n}=6$; lipogenic diet: $\mathrm{n}=7$ ) for analysis of milk yield, energy in milk, and milk fat, protein, and lactose (model 1 ) or 6 climate respiration chambers $(n=3$ per dietary treatment per lactation week) for analysis of $\mathrm{GE}, \mathrm{ME}$, methane production, $\mathrm{HP}, \mathrm{ER}, \mathrm{ER}_{\mathrm{p}}$, and $\mathrm{ER}_{\mathrm{f}}$ (model 2). Although multiple measurements per animal cannot be regarded as independent units of observation, repeatedmeasures ANOVA (Littell et al., 2006; SAS, version 9.1) was performed. Cow (model 1) or chamber (model 2) was included as the repeated subject. Diet (glucogenic or lipogenic), week (wk 2 to $9 \mathrm{pp}$ ), and their interaction were included in the model as fixed effects. In case of lack of significance $(P>0.05)$, the diet $\times$ week interaction was excluded from the model. A first-order autoregressive structure $[\mathrm{AR}(1)]$ was the best fit and was used to account for within-cow variation (model 1) or withinchamber variation (model 2). Model assumptions were evaluated by examining the distribution of residuals. Values are presented as least squares means with their SEM.

\section{RESULTS}

\section{Animal Performance}

Body weight $(595 \pm 14 \mathrm{~kg})$ and $\mathrm{BCS}(2.7 \pm 0.1)$ at entry of the climate respiration chambers at $1 \mathrm{wk} p \mathrm{p}$ were not different between dietary treatments. At the end of the experiment (wk $9 \mathrm{pp}), \mathrm{BW}(548 \pm 13 \mathrm{~kg})$ and BCS $(2.3 \pm 0.1)$ did not differ between dietary treatments. Dry matter intake and milk yield did not differ between diets (Table 4), but both increased linearly with time pp $(P<0.05)$. Dry matter intake increased from $16.5 \mathrm{~kg} / \mathrm{d}( \pm 0.6 \mathrm{~kg} / \mathrm{d})$ in wk 2 to $22.7 \mathrm{~kg} / \mathrm{d}( \pm 0.2 \mathrm{~kg} /$ d) in wk 9 pp. Milk yield increased from $34.2 \mathrm{~kg} / \mathrm{d}( \pm 0.7$ $\mathrm{kg})$ in wk 2 to $41.5 \mathrm{~kg} / \mathrm{d}( \pm 0.7 \mathrm{~kg} / \mathrm{d})$ in wk $9 \mathrm{pp}$. Milk fat content and daily milk fat yield were higher $(P<$ 0.05 ) in cows fed the lipogenic diet compared with cows fed the glucogenic diet. Protein content, protein yield, lactose content, and lactose yield did not differ between 

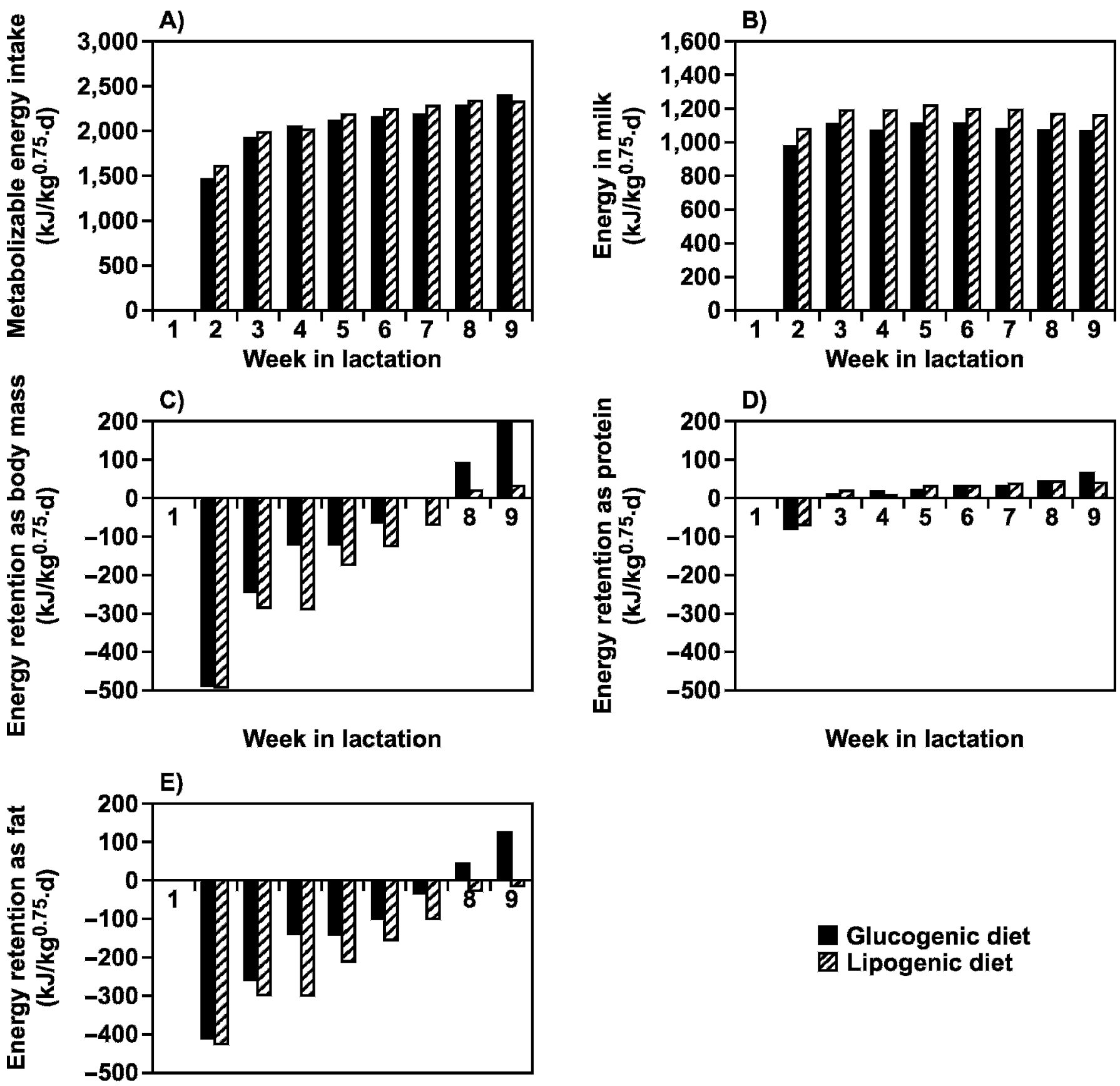

Week in lactation

\section{Week in lactation}

Figure 2. A) Metabolizable energy intake (ME); B) energy in milk ( $\left.\mathrm{NE}_{\text {milk }}\right)$; C) energy retention as body mass $(\mathrm{ER})$; D) energy retention as protein $\left(E R_{p}\right)$; and $E$ ) energy retention as fat $\left(\mathrm{ER}_{\mathrm{f}}\right)$ of dairy cows fed a mainly glucogenic or mainly lipogenic diet from wk 2 to 9 of lactation. Values represent means $\left[\mathrm{kJ} / \mathrm{kg}^{0.75} \cdot \mathrm{d}\right]$ for 3 climate respiration chambers with 2 cows each during 8 balance periods of 1 wk. Overall SEM: $\mathrm{ME}=74 ; \mathrm{NE}_{\text {milk }}=23 ; \mathrm{ER}=28 ; \mathrm{ER}_{\mathrm{p}}=7 ; \mathrm{ER}_{\mathrm{f}}=24$.

dietary treatments. Milk fat, milk protein, and milk lactose content were affected by time pp $(P<0.01$; Figure 1). Daily milk fat yield and milk protein yield were affected by the diet $\times$ week interaction $(P<0.05)$, but effects of these interactions were small.

\section{Energy Partitioning}

Gross energy intake, ME intake, methane production, and heat production were not different between diets (Table 5). Intake of ME increased $(P<0.01)$ from 
Table 6. Milk fatty acid composition of dairy cows fed a mainly glucogenic or lipogenic diet during wk 2 to 9 of lactation ${ }^{1}$

\begin{tabular}{|c|c|c|c|c|c|}
\hline \multirow[b]{2}{*}{ Fatty acid } & \multicolumn{2}{|c|}{ Diet } & \multirow[b]{2}{*}{ SEM } & \multicolumn{2}{|c|}{$P$-value ${ }^{2}$} \\
\hline & Glucogenic & Lipogenic & & Diet & Week \\
\hline & \multicolumn{2}{|c|}{$\longrightarrow \mathrm{g} / 100 \mathrm{~g}$ of fatty acids -} & & & \\
\hline $4: 0$ & 6.36 & 6.19 & 0.33 & 0.71 & 0.03 \\
\hline $6: 0$ & 2.61 & 2.23 & 0.10 & 0.02 & $<0.01$ \\
\hline 8:0 & 1.26 & 1.01 & 0.07 & 0.03 & 0.01 \\
\hline 10:0 & 2.53 & 1.93 & 0.17 & 0.03 & $<0.01$ \\
\hline $11: 0$ & 0.24 & 0.16 & 0.02 & $<0.01$ & $<0.01$ \\
\hline $12: 0$ & 2.69 & 2.44 & 0.16 & 0.29 & $<0.01$ \\
\hline 13:0 & 0.09 & 0.07 & 0.01 & $<0.01$ & $<0.01$ \\
\hline Total short-chain & 15.80 & 14.00 & 0.66 & 0.07 & $<0.01$ \\
\hline $14: 0$ & 9.81 & 8.48 & 0.36 & 0.02 & $<0.01$ \\
\hline $14: 1$ & 0.67 & 0.49 & 0.04 & 0.01 & $<0.01$ \\
\hline $15: 0$ & 0.67 & 0.65 & 0.04 & 0.64 & 0.03 \\
\hline $16: 0$ & 29.17 & 31.47 & 0.71 & 0.03 & $<0.01$ \\
\hline $16: 1$ & 0.98 & 1.30 & 0.20 & 0.26 & 0.07 \\
\hline Total medium-chain & 41.34 & 42.38 & 0.97 & 0.44 & $<0.01$ \\
\hline $17: 0$ & 0.91 & 0.71 & 0.12 & 0.25 & $<0.01$ \\
\hline $17: 1$ & 0.25 & 0.19 & 0.02 & 0.02 & $<0.01$ \\
\hline $18: 0$ & 12.62 & 14.16 & 0.40 & 0.02 & $<0.01$ \\
\hline $18: 1$ & 25.74 & 25.41 & 1.05 & 0.82 & $<0.01$ \\
\hline $18: 2$ & 2.25 & 2.05 & 0.18 & 0.42 & 0.08 \\
\hline $18: 3$ & 0.55 & 0.45 & 0.02 & $<0.01$ & 0.72 \\
\hline $20: 0$ & 0.42 & 0.34 & 0.13 & 0.64 & 0.01 \\
\hline $20: 1$ & 0.07 & 0.06 & 0.01 & 0.32 & 0.84 \\
\hline $20: 4$ & 0.02 & 0.03 & 0.01 & 0.38 & $<0.01$ \\
\hline $22: 0$ & 0.02 & 0.03 & 0.01 & 0.19 & 0.24 \\
\hline CLA & 0.34 & 0.37 & 0.04 & 0.55 & 0.02 \\
\hline Total long-chain & 42.85 & 43.42 & 1.28 & 0.66 & $<0.01$ \\
\hline
\end{tabular}

${ }^{1}$ Values are least squares means.

${ }^{2}$ Diet $\times$ week interaction was not significant $(P>0.05)$ for any of the variables.

wk 2 to $9 \mathrm{pp}$ (Figure 2). The ME:GE ratio was not different between diets, but increased $(P<0.01)$ from wk 2 to 9 pp. Energy in milk was higher $(P<0.05)$ for cows fed the lipogenic diet compared with cows fed the glucogenic diet. Energy retention tended to be lower $(P=0.12)$ for cows fed the lipogenic diet compared with cows fed the glucogenic diet. Specifically, $\mathrm{ER}_{\mathrm{p}}$ did not differ between diets, but diets tended $(P=0.09)$ to be different for $\mathrm{ER}_{\mathrm{f}}$. For both diets, $\mathrm{ER}_{\mathrm{p}}$ was positive from wk 3 pp. Moreover, $\mathrm{ER}_{\mathrm{f}}$ was positive from wk $8 \mathrm{pp}$ for cows fed the glucogenic diet, whereas $\mathrm{ER}_{\mathrm{f}}$ was still negative $\left[-11 \pm 39 \mathrm{~kJ} /\left(\mathrm{kg}^{0.75} \cdot \mathrm{d}\right)\right]$ in wk $9 \mathrm{pp}$ for cows fed the lipogenic diet.

\section{Milk Fat Composition}

Of the short-chain fatty acids in milk fat, C6:0, C8:0, C10:0, C11:0, and C13:0 were higher for cows fed the glucogenic diet compared with cows fed the lipogenic $\operatorname{diet}(P<0.05$; Table 6$)$. Of the medium-chain fatty acids, the concentrations of C14:0 and C14:1 in milk fat were higher for cows fed the glucogenic diet $(P<0.05)$, and C16:0 was higher for cows fed the lipogenic $\operatorname{diet}(P<$ $0.05)$. Of the long-chain fatty acids, the concentration of C18:0 was higher and C18:3 was lower $(P<0.05)$ for cows fed the lipogenic diet compared with cows fed the glucogenic diet. Total production of milk fatty acids was $195 \mathrm{~g}$ of fatty acids per day more for cows fed the lipogenic diet compared with cows fed the glucogenic diet. This increase in milk fatty acid production could be explained almost entirely by an increase in secretion of C16:0 (96 g/d), C18:0 (51 g/d), and C18:1 (45 g/d). The daily production of medium-chain fatty acids $(\geq \mathrm{C} 14$ and $\leq$ C16) in milk fat increased linearly with week in lactation (Figure 3). The production of long-chain fatty acids (>C16) decreased linearly from wk 2 until wk 9 in lactation.

\section{DISCUSSION}

This study agrees with other studies that observed an increase in milk fat percentage after feeding more lipogenic nutrients (e.g., Grum et al., 1996; Moallem et al., 1999). However, those studies not only increased the proportion of lipogenic nutrients, but also the energy density and energy intake by adding lipogenic nutrients to the diet. Consequently, milk yield increased in the treatment group compared with the control diet. Feeding extra glucogenic nutrients, accompanied by an increase in energy intake, resulted in an increase in milk 

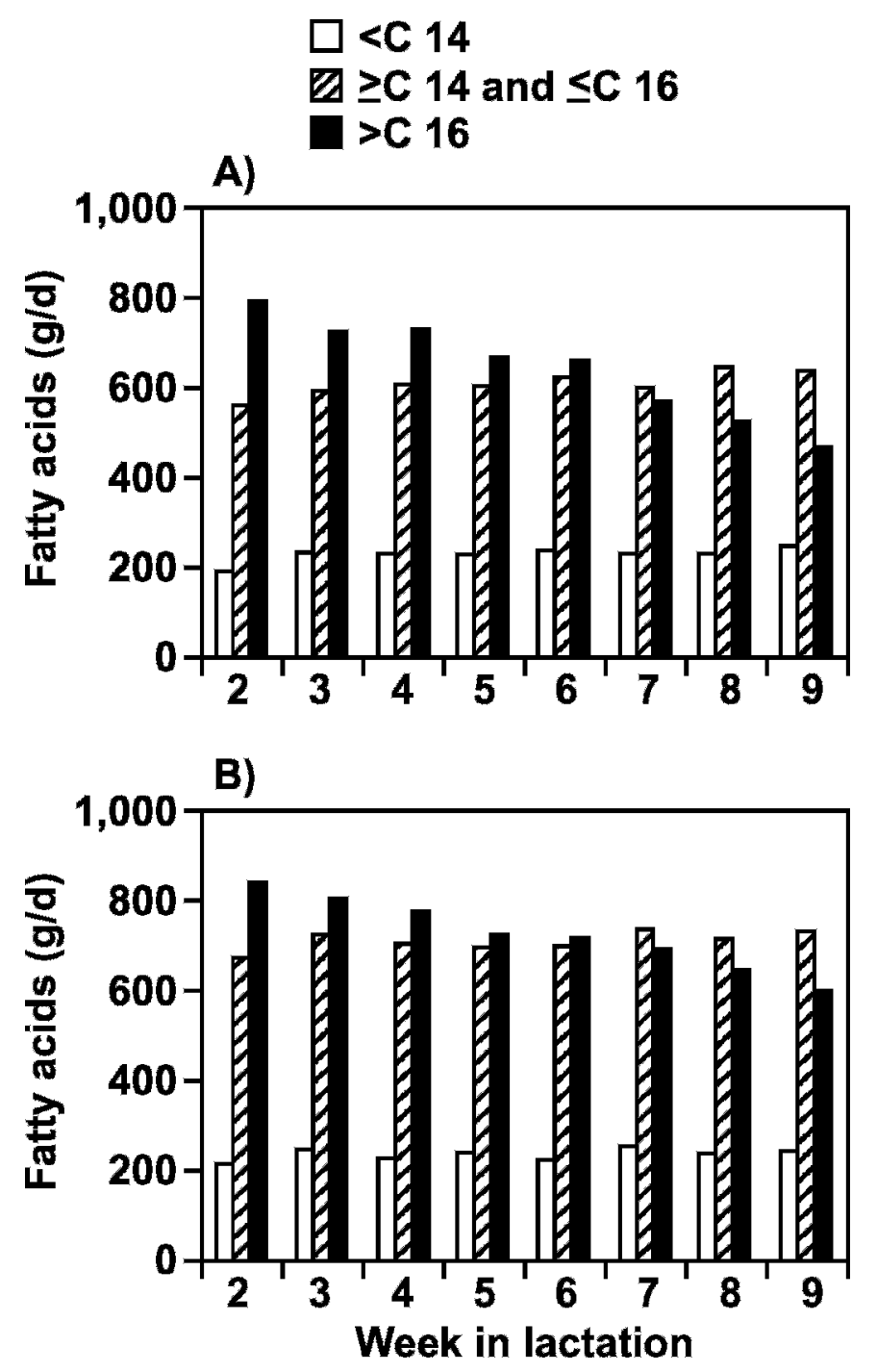

Figure 3. A) Milk fatty acid production (g/d) of dairy cows fed a mainly glucogenic diet from wk 2 to 9 in lactation; B) milk fatty acid production $(\mathrm{g} / \mathrm{d})$ of dairy cows fed a mainly lipogenic diet from wk 2 to 9 in lactation. Values represent means per week. SEM for cows fed the glucogenic diet: $<\mathrm{C} 14=58 ; \geq \mathrm{C} 14$ and $\leq \mathrm{C} 16=86 ;>\mathrm{C} 16=128$. SEM for cows fed the lipogenic diet: $<\mathrm{C} 14=39$; $\geq \mathrm{C} 14$ and $\leq \mathrm{C} 16=$ $63 ;>\mathrm{C} 16=100$

yield (Grum et al., 1996; Hurtaud et al., 2000). However, extra glucogenic nutrients often decreased the milk fat percentage and increased the milk protein percentage. In contrast to these studies, the present study was designed to feed isocaloric diets with a contrast in lipogenic and glucogenic nutrient content. As a result, GE and ME intakes were not different between diets. Despite a similar quantity of available ME, cows fed the lipogenic diet partitioned more energy to milk compared with cows fed the mainly glucogenic diet. The increased partitioning of energy to milk resulted in an increase in milk fat production, but had no effect on total milk yield or milk protein yield.

In the current study, cows fed the glucogenic diet seemed to lower the priority of milk fat production as indicated by a lower milk energy output, and increased the priority of energy retention in body reserves as indicated by the numerically increased energy balance. This observation is in agreement with the review of Van Soest (1963), who suggested that milk-fat-depressing diets lower the priority of milk production relative to body reserves. In the present experiment, dietary energy source did not alter the body protein balance, but specifically the body fat balance was less negative with feeding a more glucogenic diet. Concerning the period of wk 2 to $9 \mathrm{pp}$, cows fed the glucogenic diet mobilized $18.6 \mathrm{~kg}$ of body fat $(1 \mathrm{~g}$ of body fat $=39.8 \mathrm{~kJ}$; Wenk et al., 2001) compared with $31.2 \mathrm{~kg}$ for cows fed the mainly lipogenic diet. Cows fed the lipogenic diet mobilized 226 $\mathrm{g} / \mathrm{d}$ more body fat compared with cows of comparable $\mathrm{BW}, \mathrm{BCS}$, and milk yield but fed the mainly glucogenic $\operatorname{diet}(332 \mathrm{vs} .558 \mathrm{~g} / \mathrm{d}$ of body fat, respectively). The difference in body fat mobilization is in accordance with 220 $\mathrm{g} / \mathrm{d}$ more milk fat produced for cows fed the lipogenic diet compared with cows fed the glucogenic diet. After subtracting body fat mobilization from milk fat production, cows fed the glucogenic diet produced 1,348 g/d of milk fat from ME intake compared with 1,342 g/d of milk fat for cows fed the lipogenic diet. This suggests the extra milk fat production for cows fed the lipogenic diet originated predominantly from body fat mobilization that was increased by $68 \%$ compared with cows fed a mainly glucogenic diet.

Energy retention as protein was positive for both treatment groups from wk $3 \mathrm{pp}$ onward, which is in agreement with Tamminga et al. (1997), who estimated changes in body composition with time after parturition. They reported that body protein mobilization stabilized from wk $2 \mathrm{pp}$ and body protein gain stabilized from wk $4 \mathrm{pp}$. Total estimated mobilization of body reserves during the first $8 \mathrm{wk}$ of lactation was $41.6 \mathrm{~kg}$ and included $30.9 \mathrm{~kg}$ of body fat and $2.4 \mathrm{~kg}$ of body protein (Tamminga et al., 1997). This corresponds with the current study, where on average the cows mobilized $24.9 \mathrm{~kg}$ of body fat and $5.2 \mathrm{~kg}$ of body protein ( $1 \mathrm{~g}$ of body protein $=23.6 \mathrm{~kJ}$; ARC, 1980) from wk 2 to wk 9 in lactation.

The results confirm the hypothesis that a mainly lipogenic diet during early lactation increases the secretion of long-chain fatty acids in milk fat compared with a mainly glucogenic diet. Because the lipogenic diet has a higher dietary fat content, and because body fat mobilization is higher compared with cows fed the glucogenic diet, it can be suggested that both sources of long-chain fatty acids (dietary and endogenous) contribute to the 
increased secretion of long-chain fatty acids in milk fat of cows fed the lipogenic diet. As well as the diet treatment, negative energy status also seems to have an effect on milk fat composition. A decrease from early to mid lactation in the production of long-chain fatty acids relative to medium-chain fatty acids has been reported earlier (Garnsworthy et al., 2006). This corresponds with the current study showing that with increasing energy balance during wk 2 to $9 \mathrm{pp}$, the daily production of medium-chain fatty acids ( $\geq$ C14:0 and $\leq \mathrm{C} 16: 0)$ increased and at the same time the production of longchain fatty acids ( $\geq \mathrm{C} 18: 0)$ decreased (Figure 3 ).

\section{CONCLUSIONS}

This study confirmed the hypothesis that energy partitioning between milk and body tissue can be altered by feeding isocaloric diets that differ in lipogenic and glucogenic nutrient content. Although ME intake was not different, daily milk fat yield and energy in milk were higher in the lipogenic diet group. Consequently, the higher milk energy resulted in a tendency for less energy to be partitioned into body fat for cows fed the lipogenic diet compared with cows fed the glucogenic diet.

\section{ACKNOWLEDGMENTS}

The authors thank the Product Board Animal Feed (PDV) and Dutch Dairy Board (PZ) for the financial support of this experiment. Additionally, the authors wish to thank Koos van der Linden, Tamme Zandstra, and Sven Alferink for technical support during the experiment and Dick Bongers and Miriam de Laat for the FAME analysis.

\section{REFERENCES}

Adler, J. H. 1970. Theoretical quantitative approach to the mechanism of hypoglycemic ketosis in ruminants. J. Theor. Biol. 28:101-109.

ARC. 1980. The Nutrient Requirements of Ruminant Livestock. Commonwealth Agricultural Bureau, Slough, UK.

Baldwin, B. R., N. E. Forsberg, and C. Y. Hu. 1985. Potential for altering energy partition in the lactating dairy cow. J. Dairy Sci. 68:3394-3402.

Bannink, A., J. Kogut, J. Dijkstra, J. France, E. Kebreab, A. M. Van Vuuren, and S. Tamminga. 2006. Estimation of the stoichiometry of volatile fatty acid production in the rumen of lactating cows. J. Theor. Biol. 238:36-51.

Bauman, D. E., and J. M. Griinari. 2003. Nutritional regulation of milk fat synthesis. Annu. Rev. Nutr. 23:203-227.

Bauman, D. E., I. H. Mather, R. J. Wall, and A. L. Lock. 2006. Major advances associated with the biosynthesis of milk. J. Dairy Sci. 89:1235-1243.

Baumgard, L. H., J. K. Sangster, and D. E. Bauman. 2001. Milk fat synthesis in dairy cows is progressively reduced by increasing supplemental amounts of trans-10, cis-12 conjugated linoleic acid (CLA). J. Nutr. 131:1764-1769.

Brockman, R. P. 2005. Glucose and short-chain fatty acid metabolism. Pages 291-310 in Quantitative Aspects of Ruminant Digestion and Metabolism. J. Dijkstra, J. M. Forbes, and J. France, ed. $\mathrm{CAB}$ International, Wallingford, UK.

Butler, W. R. 2003. Energy balance relationships with follicular development, ovulation and fertility in postpartum dairy cows. Livest. Prod. Sci. 83:211-218.

Centraal Veevoederbureau (CVB). 2005. Veevoedertabel. Gegevens over chemische samenstelling, verteerbaarheid en voederwaarde van voedermiddelen. CVB, Lelystad, the Netherlands.

Chilliard, Y., and A. Ferlay. 2004. Dietary lipids and forages interactions on cow and goat milk fatty acid composition and sensory properties. Reprod. Nutr. Dev. 44:467-492.

Garnsworthy, P. C., L. L. Masson, A. L. Lock, and T. T. Mottram. 2006. Variation of milk citrate with stage of lactation and de novo fatty acid synthesis in dairy cows. J. Dairy Sci. 89:1604-1612.

Gong, J. G. 2002. Influence of metabolic hormones and nutrition on ovarian follicle development in cattle: Practical implications. Domest. Anim. Endocrinol. 23:229-241.

Grum, D. E., J. K. Drackley, L. R. Hansen, and J. D. Cremin. 1996. Production, digestion, and hepatic lipid metabolism of dairy cows fed increased energy from fat or concentrate. J. Dairy Sci. 79:1836-1849.

Grummer, R. R. 1993. Etiology of lipid-related metabolic disorders in periparturient dairy cows. J. Dairy Sci. 76:3882-3896.

Grummer, R. R., and D. J. Carroll. 1988. A review of lipoprotein cholesterol metabolism: Importance to ovarian function. J. Anim. Sci. 66:3160-3173.

Hurtaud, C., S. Lemosquet, and H. Rulquin. 2000. Effect of graded duodenal infusions of glucose on yield and composition of milk from dairy cows. 2. Diets based on grass silage. J. Dairy Sci. 83:2952-2962.

Jerred, M. J., D. J. Carroll, D. K. Combs, and R. R. Grummer. 1990. Effect of fat supplementation and immature alfalfa to concentrate ratio on lactation performance of dairy cattle. J. Dairy Sci. 73:2842-2854.

Littell, R. C., G. A. Milliken, W. W. Stroup, R. D. Wolfinger, and O. Schabenberger. 2006. SAS ${ }^{\circledR}$ for Mixed Models. 2nd ed. SAS Institute Inc., Cary, NC.

Mills, J. A. N., J. France, and J. Dijkstra. 1999. A review of starch digestion in the lactating dairy cow and proposals for a mechanistic model: 2. Postruminal starch digestion and small intestinal glucose absorption. J. Anim. Feed Sci. 8:451-481.

Miyoshi, S., J. L. Pate, and D. L. Palmquist. 2001. Effects of propylene glycol drenching on energy balance, plasma glucose, plasma insulin, ovarian function and conception in dairy cows. Anim. Reprod. Sci. 68:29-43.

Moallem, U., Y. Folman, A. Bor, A. Arav, and D. Sklan. 1999. Effect of calcium soaps of fatty acids and administration of somatotropin on milk production, preovulatory follicular development, and plasma and follicular fluid lipid composition in high yielding dairy cows. J. Dairy Sci. 82:2358-2368.

Owens, F. N., D. S. Secrist, W. J. Hill, and D. R. Gill. 1998. Acidosis in cattle: A review. J. Anim. Sci. 76:275-286.

Palmquist, D. L., A. D. Beaulieu, and D. M. Barbano. 1993. Feed and animal factors influencing milk fat composition. J. Dairy Sci. 76:1753-1771.

Ruppert, L. D., J. K. Drackley, D. R. Bremmer, and J. H. Clark. 2003. Effects of tallow in diets based on corn silage or alfalfa silage on digestion and nutrient use by lactating dairy cows. J. Dairy Sci. 86:593-609.

Schroeder, G. F., J. E. Delahoy, I. Vidaurreta, F. Bargo, G. A. Gagliostro, and L. D. Muller. 2003. Milk fatty acid composition of cows fed a total mixed ration or pasture plus concentrates replacing corn with fat. J. Dairy Sci. 86:3237-3248.

Smith, N. E., W. L. Dunkley, and A. A. Franke. 1978. Effects of feeding protected tallow to dairy cows in early lactation. J. Dairy Sci. 61:747-756.

Tamminga, S., P. A. Luteijn, and R. G. M. Meijer. 1997. Changes in composition and energy content of liveweight loss in dairy cows with time after parturition. Livest. Prod. Sci. 52:31-38.

Tamminga, S., W. M. Van Straalen, A. P. J. Subnel, R. G. M. Meijer, A. Steg, C. J. G. Wever, and M. C. Blok. 1994. The Dutch protein 
evaluation system: The DVE/OEB-system. Livest. Prod. Sci. 40:139-155.

Van Es, A. J. H. 1975. Feed evaluation for dairy cows. Livest. Prod. Sci. 2:95-107.

van Knegsel, A. T. M., H. van den Brand, J. Dijkstra, S. Tamminga, and B. Kemp. 2005. Effect of dietary energy source on energy balance, production, metabolic disorders and reproduction in lactating dairy cattle. Reprod. Nutr. Dev. 45:665-688.

van Knegsel, A. T. M., H. van den Brand, E. A. M. Graat, J. Dijkstra, R. Jorritsma, E. Decuypere, S. Tamminga, and B. Kemp. 2007. Dietary energy source in dairy cows in early lactation: Metabolites and metabolic hormones. J. Dairy Sci. 90:1477-1485.

Van Soest, P. J. 1963. Ruminant fat metabolism with particular reference to factors affecting low milk fat and feed efficiency. A review. J. Dairy Sci. 46:204-216.

Veerkamp, R. F., B. Beerda, and T. Van der Lende. 2003. Effects of genetic selection on milk yield on energy balance, levels of hormones, and metabolites in lactating dairy cattle, and possible links to reduced fertility. Livest. Prod. Sci. 83:257-275.

Verstegen, M. W. A., W. Van der Hel, H. A. Brandsma, A. M. Henken, and A. M. Bransen. 1987. The Wageningen respiration unit for animal production research: A description of the equipment and its possibilities. Pages 21-48 in Energy Metabolism in Farm Animals: Effects of Housing, Stress and Disease. M. W. A. Verstegen and A. M. Henken, ed. Martinus Nijhoff Publishers, Dordrecht, the Netherlands.

Ward, A. T., K. M. Wittenberg, and R. Przybylski. 2002. Bovine milk fatty acid profiles produced by feeding diets containing solin, flax and canola. J. Dairy Sci. 85:1191-1196.

Wenk, C., P. C. Colombani, J. van Milgen, and A. Lemme. 2001. Glossary: Terminology in animal and human energy metabolism. Pages 409-421 in Proc. 15th Symp. Energy Metabolism in Animals, Snekkersten, Denmark. A. Chwalibog and K. Jakobsen, ed. Wageningen Pers, Wageningen, the Netherlands. 